\title{
Influence of Policy Implementation Practices on Employee Development in the Eastern Region of the Presbyterian Church of East Africa, Kenya
}

\author{
Samuel Riungu Muratha ${ }^{1 *}$ Paul Gesimba ${ }^{2}$ David Gichuhi ${ }^{3}$ \\ 1. Faculty of Social Sciences, St. Paul's University, PO Box Private Bag, Limuru, Kenya \\ 2. Faculty of Social Sciences, St. Paul's University, PO Box Private Bag, Limuru, Kenya
}

3. School of Busines, Karatina University, PO Box ,1957, Karatina, Kenya

*E-mail of the corresponding author: samuelriungu@gmail.com

\begin{abstract}
Policy implementation involves translating the goals and objectives of a policy into an action. The success of policy implementation depends on the choice of appropriate incentives based on the local biophysical and social conditions. The Presbyterian Church of East Africa (PCEA) recognizes the importance of employee development and is committed to providing the best possible climate for maximum personal development and goal achievement for each employee. Human resources management in PCEA is guided by a document known as the schemes of service. This document guides the job and career prospects for all cadres of personnel. They include, Church administrators, accountants and bookkeepers, secretaries, gardeners, caretakers, cleaners and security guards. Like many mainstream churches, the PCEA is facing a challenge of staff turnover. Despite this challenge, little information regarding leadership practices that influence employee development in the Kenyan context exists. The study examined the influence of policy implementation practices by church leadership on employee development. A descriptive research design using survey method was adopted. The study targeted 291 Church leaders comprising of 255 elected leaders from the 47 Parishes and 4 mission areas and 36 elected leaders drawn from the 9 Presbyteries of Eastern Region of PCEA. Stratified sampling method was used to select a sample of 145 parish leaders and 20 Presbytery leaders totaling to 165 respondents. Data was collected using mainly questionnaires. A pilot study was conducted in Mount Kenya region of PCEA. Descriptive and inferential statistics were used for data analysis. The main findings show that leaders in PCEA implemented non-formal training, financed employees, and offered them study leaves with pay and promotions to promote employee development. However, a gap onthe-job training was established. It is time the Church shifts the paradigm to embrace on-the-job training of her employees. If the PCEA has to be successful in her mission in the $21^{\text {st }}$ century, it has to reconsider her on-the-job training systems.
\end{abstract}

Keywords: Employee Development, PCEA, Policy Practices

DOI: $10.7176 / \mathrm{JPCR} / 50-07$

Publication date:October $31^{\text {st }} 2020$

\section{Introduction}

Professional development is directly related to the day-to-day activities of workers and should be part of a broader process of continuous learning (Hill, Beisiegel \& Jacob, 2013). It is composed of a series of events and activities related to a particular profession, creating or developing sets of skills, knowledge, and attitudes in the areas of people's performance (Dobos, 2014). Professional development encompasses a variety of practices, such as: inservice training (Stewart, 2014); participation in communities of practice (Korthagen, 2017); participation in processes of continuous professional development (Kock, Ellström, 2011); peer collaboration mediated by technological resources (Lauber, Taylor, Decker \& Knuth, 2010); mentoring programs (Shah, Sultana, Hassain \& Ali, 2011); and specific leadership development programs (Korthagen, 2017). In this sense, the focus of the concept of professional development is on a combination of cognitive, affective, and behavioural processes, involving formal and informal learning strategies throughout the career. Professional development corresponds to the growth and maturation of the knowledge, skills, and attitudes acquired throughout the workers' lives, as a result of formal and informal actions of learning at work (Anagnou \& Fragoulis, 2014). In this sense, it is necessary to understand that, besides the individual characteristics, other variables such as leadership practices can influence the development process of the people. Thus, we can consider that professional development is supported by the leadership practices adopted by leaders. Therefore, a contribution of Church leaders to the professional development of their subordinates needed to be further explored.

A study conducted in the United States shows that most chief executives believe that building and maintaining a skilled workforce is the most important challenge of the decade (Allen, 2015). Although this research was done at the beginning of the $21^{\text {st }}$ century, the challenge of developing and maintaining a properly qualified workforce is 
still present not only for American organizations but also as a global challenge. In Brazil, a survey of 1150 organizations (public, private, and third sector) identified that $42 \%$ of organizations invest in training actions within or outside the workplace (Lauber et al, 2010). These results allow an association between the growth of the organization and the level of investment in the professional development of the employees. These results suggest, therefore, that investing in leadership can be useful in shifting the value attributed to the professional development of the workforce.

In Africa, there is a growing concern that people management policies are not aligned with the organizational strategy and value for their employees (Burnes \& Jackson, 2011). Leaders need to invest in the development of employee competencies.

Nkonge (2014) avers that dependable leaders are an essential component of any developing community. Therefore, the performance of the leader can be of great relevance for the professional development of the subordinates, since the leadership can establish strategies of qualification, as well as create a favourable environment for learning. Consequently, research on leadership practices and church employee growth in Africa remains critical. The leadership of the church is a very crucial element of the church growth and employee development in the current church setting (Kariuki, 2019).

Mainstream Churches in Kenya have experienced tremendous growth as compared to the earlier times. However, this growth has come with challenges ranging from leadership wrangles, management challenges as well as poor employee development (Rukenya, 2019; Kariuki, 2019). The PCEA which has more than 4,000,000 million members, over 1500 congregations, over 500 parishes, and 55 presbyteries in Kenya and Tanzania is experiencing challenges on how to remain meaningful, relevant, effective, and fruitful ( Kariuki, 2019; Momanyi \& Kaimenyi, 2015; Mathenge, 2015). A study by Ngeere (2012) reports high turnover of staff working in the Eastern region of PCEA commonly moving to Nairobi, Central, Eastern, Mount Kenya and Rift Valley Region. Momanyi and Kaimenyi aver that employee turnover in PCEA Eastern region has a cyclic nature and remains a challenging issue. A high turnover rate leads to inability of the Church to provide quality services to adherents (Rukenya, 2019).

Miyuki (2009) found that personnel turnover poses a significant problem through loss of trained employees and is even more problematic when the supply of such skilled and knowledgeable employees is limited, thus leading to a permanent loss of productivity. Unless this situation is ameliorated, the church will experience problems in maintaining sufficient numbers of employees to provide services to her followers and the community. Previous studies have scanty information relating leadership practices with employee encouragement and attitudes. This is an indication that the turnover has a significant impact on the Church progression in this region. Therefore, there was need to re-evaluate, reflect, re-examine and assess the leadership practices and employee development in the PCEA. This study therefore investigated influence of leadership practices (policy implementation) on employee development in the Eastern Region of the Presbyterian Church of East Africa.

\subsection{Literature Review}

Every institution's lifeline is entrenched in its policies, especially on human resource. Policies guide the organizations to many areas relating to well-being of the employees and that of the overall organizational health. Together with employee motivation and good leadership practices, good policies also ensure fair wages and salaries.

Selled and Hasseini (2017) insists on the need to integrate Human Resource Development strategies of any organization within the organizations strategy. This is cardinal to the areas of employee development though his research needs more elaborate methodology of date collection and analysis. It is imperative that research on this very important topic in organization human resource development was undertaken. Whereas (Lara \& Farlad, 2014) expressed the need for capacity building recommending Human Resource Procedures to be more updated especially on employee recruitment with clear appraisal systems and clear training and development systems, their research basically are more on leadership vested in the chief executive officer than that of organization governed through councils. Again there is need to broaden the scope of sampling.

Some institutions have very sound policies on personal development but as Emmanuel and Millie (2015) notes there are factors that influence implementation of these policies that range from involvement of beneficiaries in the formulation of the policies, to communication of the same and social condition of the community, society of 
the country that implementation will take place. This again needs to be researched in particular localities.

Implementation of policies by the leaders will ensure a good working environment, assurance of healthcare and retirement (Krishnand, 2013). On the other hand, good policies will solve turnover problems and enhance better performances. Krishnand advocates for more research in policy issues in leadership and management. Danskaren's (2017) posits that purposeful sampling with semi-structured interviews is not sufficient but who brings into light a very important issue on organizational policies and how they should support employees on achieving work life reconciliation. According to this author, there is need for gender consideration in policies, occupational healthcare and professional guidance. More research needed to be done on this.

\section{Conceptual Framework}

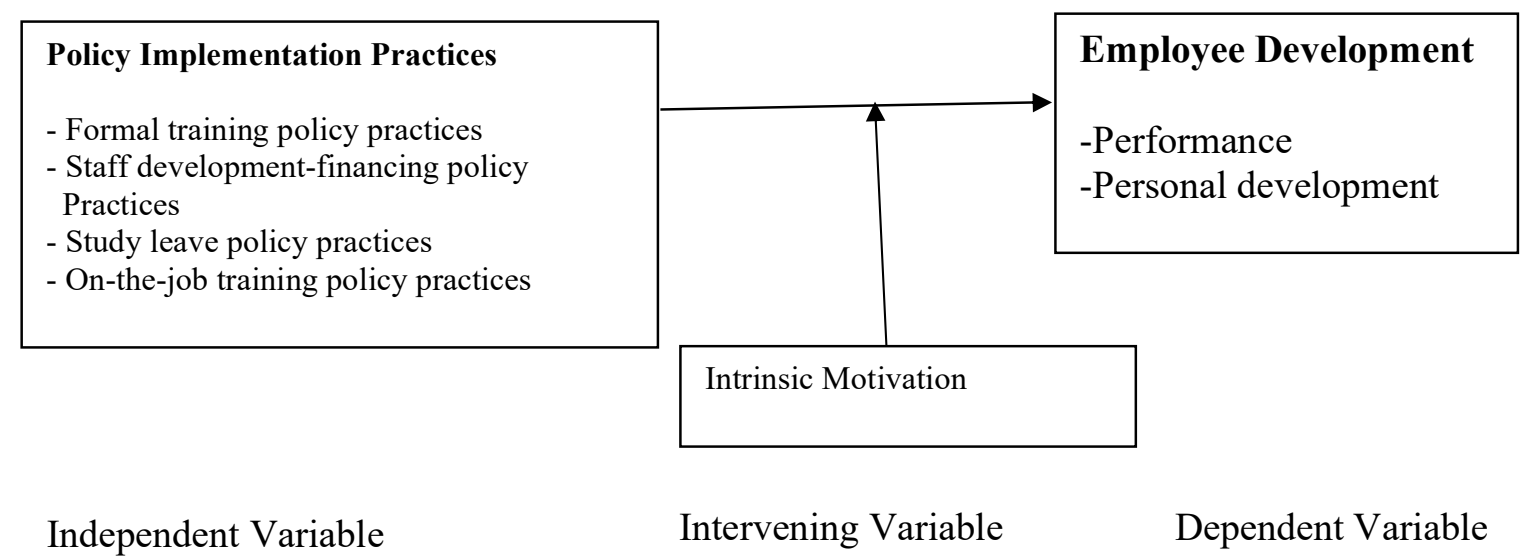

The conceptual frameworks shows that the independent variable is policy implementation practices while employee development is the dependent variable. It is worth noting that leadership practices such as the ones investigated play a major role in employee professional development. This rationalizes the study on how their application influences employee development within the realms of the Church.

\subsection{Methodology}

A descriptive research design using survey method was adopted. Descriptive research is a research method that describes the characteristics of the population or phenomenon that is being studied (Nardi, 2015). The design was an appropriate choice for this study because the research aimed at identifying leadership practices employed in influencing staff development in PCEA since not much was known about the study variables. By using the survey method, the study collected the information needed without manipulation of the study variables. It was also possible to collect data from the respondents without influencing them.

The study was carried out in the Eastern Region of the Presbyterian Church of East Africa in Kenya. Eastern Region consists of 47 parishes and 4 mission areas within the 9 Presbyteries and geographically covers Tharaka Nithi and Meru Counties. The target population for this study comprised of 255 Parish leaders drawn from 47 parishes and 4 Mission areas, and 36 Presbytery leaders drawn from the nine Presbyteries of the Eastern Region of the PCEA totalling to 291. The justification for the selection of Eastern region of PCEA in Kenya was based on several considerations. First, a study of clergy in the PCEA reveals that rural clergy in Eastern region report high turnover migrating from rural to urban areas (PCEA records, 2019). Second, rural clergy face several unique challenges (such as multi-church ministry and lower salaries), contributing to the high turnover. Third, clergy opt out of rural areas of Eastern region because they do not have sufficient social and personal resources (Rural Poverty, 2010) which suggests that rural ministry might be different as well. Anthropologist Sonya Salamon (2003) notes that high rates of rural to urban migration of church employees can spark changes in community priorities and a loss of local identity.

Stratified sampling was used to select the Parish and Presbytery leaders in the proportion to the way they occurred in the population. Questionnaires were administered to 165 respondents. A pilot study was carried out in Mount Kenya region of PCEA. The supervisors of this study and other experts in the Department of education at St. Pauls evaluated the items in the questionnaires to find out if they would truly measure what they were intended to 
measure and whether the questionnaire items included all the content of a particular construct and advised accordingly. Reliability of the research instruments was assessed using the Cronbach's Alpha Coefficient. The results found that the range of Cronbach's Alpha Coefficient was 0.721 for parish leaders' questionnaire and 0.723 for presbytery moderators' questionnaire. This resulted in a mean of 0.722 on the reliability test. Fraenkel and Wallen (2009) recommend a reliability coefficient of 0.70 and above. Therefore, a reliability coefficient of 0.722 was considered adequate for the study.

Data analysis entailed doing mathematical computations on the data obtained from the field to generate useful information to facilitate cogent discussion and draw inferences. Data was cleaned, coded and entered in the computer for analysis using Statistical Package for Social Sciences (SPSS) version 21 for windows. Data was analysed quantitatively using descriptive and inferential statistics. Regression analysis determine if policy implementation practices had a significant influence on employee development.

\subsection{Results and Discussions}

\subsection{Policy Implementation Practices and Employee Development}

The study determined how policy implementation practices influence employee development in the Eastern Region of the Presbyterian Church of East Africa. Presented are the results of the analysis.

Table 1: Policy Implementation Practices Regarding Employee Development

\begin{tabular}{|c|c|c|c|c|c|c|c|c|c|c|c|}
\hline \multirow[t]{3}{*}{ Policy Practices } & \multicolumn{10}{|c|}{$\begin{array}{c}\text { Responses } \\
\mathrm{n}=165\end{array}$} & \multirow{3}{*}{ Mean } \\
\hline & \multicolumn{2}{|c|}{ SA } & \multicolumn{2}{|c|}{ A } & \multicolumn{2}{|c|}{ NS } & \multicolumn{2}{|c|}{$\mathrm{D}$} & \multicolumn{2}{|c|}{ SD } & \\
\hline & $\mathrm{F}$ & $\%$ & $\mathrm{~F}$ & $\%$ & $\mathrm{~F}$ & $\%$ & $\mathrm{~F}$ & $\%$ & $\mathrm{~F}$ & $\%$ & \\
\hline Non-formal training & 55 & 33 & 20 & 12 & 26 & 16 & 28 & 17 & 36 & 22 & 3.18 \\
\hline Staff financing & 46 & 28 & 27 & 16 & 37 & 22 & 12 & 07 & 43 & 26 & 3.13 \\
\hline Study leaves & 68 & 41 & 49 & 30 & 22 & 13 & 11 & 06 & 15 & 09 & 3.87 \\
\hline On job training & 12 & 07 & 24 & 15 & 25 & 15 & 66 & 40 & 38 & 23 & 2.43 \\
\hline Staff promotion & 23 & 14 & 37 & 22 & 07 & 04 & 84 & 51 & 14 & 08 & 2.82 \\
\hline Overall Mean & & & & & & & & & & & 3.09 \\
\hline
\end{tabular}

Key: SA = Strongly Agree; $\mathrm{A}=$ Agree; NS=Not Sure; D = Disagree; SD=Strongly Disagree

The results of this study indicate that the strategies implemented by church leaders in the PCEA supported by the respondents with regard to employee development included non-formal training (Mean $=3.18$ ), financing employees to further their training (Mean $=3.13)$, Offering study leaves with pay to church employees $($ Mean $=$ 3.87), staff promotion (Mean $=2.82$ ). This implies that leaders in PCEA are influencing employee development through non-formal methods, employee financing, offering study leaves with pay as well as promoting them to enhance productivity. A discussion of the policy implementation practices is elucidated in the subsequent sections.

\subsubsection{Non-formal Training}

Non-formal training is among the most cost-effective intervention for improving human resource competencies in any organization (Rothwell, Hohne \& King, 2012). In the church, seminars and workshops play a key role in improving employee performance (Asfaw, Argaw \& Bayissa, 2015). This study examined leadership practices adopted to influence staff development in PCEA. The results show that majority $(45 \%)$ of the respondents generally agreed that the PCEA leadership implements non-formal training programs as compared with $39 \%$ that disagreed and $22 \%$ that were non-committal on this aspect. The findings in tandem with Dessler (2013) who found that non-formal training programmes are essential in keeping employees abreast with the current performance trends. The results are also congruent with Li, Tong and Wong (2014) who established that seminars and workshops provide employees with opportunities to acquire, practice and adopt new knowledge, thereby enhancing individual, group and organizational learning and capabilities.

The study further established that the PCEA has certain provisions regarding individual training programs. All employees that have worked for the church more than four months are eligible to participate in external training programs individually or in teams. Mwamba (2019) aver that the PCEA is committed to providing a supportive and rewarding environment for employees and recognizes that the quality, responsiveness and professionalism of its workforce are inextricably linked to the Church's achievement of her mission and strategic goals. 


\subsubsection{Staff Financing}

This study examined leadership practices concerning financing adopted to influence staff development in PCEA. The results of this study show that the majority (44\%) of the respondents agreed that the leadership in the church facilitated the financing of their professional development following established policies as compared with $33 \%$ that disagreed and $22 \%$ that were unsure about this. Qualitative data obtained showed that massive spending in education financing in PCEA was in equipping teachers with the necessary skills and tools. This collaborates the findings of Asim (2013), who established that employees are motivated and developed when the employer provides support to their professional development endeavours.

\subsubsection{Study Leaves}

This study examined how church leaders provision of employees with study leaves influences staff development in PCEA. The results indicate that majority $(71 \%)$ of the respondents agreed that the leadership in PCEA offering study leaves with pay to employees to pursue professional development as compared with $15 \%$ that disagreed and $13 \%$ that were non-committal. This implies that the PCEA has an implicit policy on study leave implemented by leaders. The purpose of the study leave is to enhance the professional abilities of the employee, which shall mutually beneficial to both the employee and the Church. This is supported by Gunter (2016) findings that many churches offer employees study leave to enable them to pursue further training related to their roles not only to make them useful in their local church, but the whole Church.

\subsubsection{On Job Training}

The results obtained show that the majority $(63 \%)$ of the respondents generally disagreed that the leadership in PCEA facilitating periodic on the job training for employees in the presbyteries to promote work efficiency as compared with $12 \%$ that agreed and $15 \%$ remaining non-committal. This implies that employees working for the PCEA were not receiving on-the-job training to enable them to acquire the relevant skills, knowledge, values, attitudes and competencies as well as understanding their organization's culture to effectively discharge their mandate and manage the church in the ever-changing global environment. This concurs with Nkonge (2014) findings that the majority of the clergy in the Anglican Church of Kenya (ACK) is not receiving on the job training to match the rapidly changing Kenyan society.

\subsubsection{Employee Promotion}

This study sought to assess the effect of promotion practices on employee commitment to pursue professional development in the Eastern Region of the Presbyterian Church of East Africa. The results of this study show that a significant percentage (59\%) disagreed, $36 \%$ agreed while $4 \%$ were non-committal that promotion of employees enhanced professional development hence improving work efficiency. This implies that the implementation of promotion practice and its implications towards employees' professional development and performance is yet to be envisaged in PCEA.

The PCEA scheme of service (2010-2013) stipulate job and career prospects for all cadres of personnel, clearly describes the jobs, and give details of entry and promoting conditions where a vacancy exists. However, from the findings of this study, it is evident that though most of the PCEA leadership implements promotion practices, this is not aimed at influencing employee development. The findings agree with the views of Gibbs (2016) that organizations promote employees to maintain them and avoid turnover. The results of this study suggest that employee promotion should not only be considered as a means of merely rewarding employees but also should be taken as a means towards stimulating them to pursue professional development. Therefore, the promotion of employees in PCEA should be carefully implemented to enhance efficiency and effectiveness in the work operations of employees.

Regression analysis was conducted to determine how policy implementation practices influence employee development in the Eastern Region of the Presbyterian Church of East Africa. A mean of responses to the fivepoint Likert scale was computed for each variable. This was necessary to test the null hypothesis that there was no statistically significant influence in the implementation of various practices on employees' professional development and efficiency in the Eastern Region of the PCEA.

The results obtained are presented in Table 4.5. 
Table 2: Regression Analysis on Influence of Policy Implementation Practices on Employees' Professional Development

\begin{tabular}{lccccc}
\hline \multirow{2}{*}{ Model } & \multicolumn{3}{c}{ Unstandardized Coefficients } & \multicolumn{3}{c}{ Standardized Coefficients } \\
\cline { 2 - 6 } & $\mathrm{B}$ & Std. Error & Beta & $\mathrm{t}$ & sig \\
\hline Constant & 39.20 & 4.831 & .000 & 7.296 & .000 \\
Policy Factors: & & & & & \\
Training \& Personnel development & .025 & .167 & .012 & .147 & .001 \\
Staff Financing & .074 & .112 & .055 & .663 & .001 \\
Study Leaves & .002 & .090 & .013 & .023 & .001 \\
On Job Training & .005 & .007 & .004 & .022 & .508 \\
& & & & & \\
Staff promotion & .004 & .017 & .065 & .022 & .001 \\
\hline $\mathrm{N}=165 ; \mathrm{p}<.05 ; * * \mathrm{p}<0.01 ; \mathrm{R}^{2}=.43 ; \mathrm{F}=22.5 * *$ & & & &
\end{tabular}

Regression analysis was done to test if training and personnel development, staff financing, study leaves, on job training and staff promotion predicted employee development. The results of the regression indicates that four out of the five variables predicts employee development as explained by $43.0 \%$ of the variance $\left(\mathrm{R}^{2}=.043, \mathrm{~F}(4,185)=\right.$ $22.5, \mathrm{p}<0.01)$. The results show that personnel development (Beta $=0.012, \mathrm{p}<.001)$, staff financing $($ Beta $=.055$, $\mathrm{p}<.001)$ study leaves $($ Beta $=.013, \mathrm{p}<.001)$ and staff promotion $($ Beta $=.065, \mathrm{p}<.001)$ were significant predictors. On-the-job training $($ Beta $=.004, \mathrm{p}<.508)$ was not significant. This implies that, there is a significant relationship between training and personnel development, staff financing, study leaves and staff promotion on employees development in PCEA.

\subsection{Conclusion}

Implementation is the process that turns strategies and plans into actions in order to accomplish strategic objectives and goals. Thus, policy implementation is generally a series of activities undertaken to achieve the goals and objectives articulated in policy statements. The interplay between different practices and organisational capacity creates different scenarios to inform the development of implementation strategies. Conclusion is drawn from the findings that the Church leadership in PCEA were implementing non-formal staff development programmes, financed employees to undertake further training, and offered study leaves with pay in addition to staff promotions to enhance employee development and productivity. However, it can conclusively be stated that on the job training was lacking in practice. All the studied policy practices directly or indirectly contribute to performance; however, the importance of on the job training on performance should not be neglected. It is hard to attain a high level of performance without on-the-job training, which is a hands-on method of teaching the skills, knowledge, and competencies needed for employees to perform a specific job within the workplace. Employees learn in an environment where they will need to practice the knowledge and skills obtained during their training.

\section{Recommendations}

There is a need for the church leadership to support employee development policies and adopt strategies for the effective operation of processes that involve on-the- job training in addition to employee financing and offering study leaves and promotions that are currently under practice. On-the-job training will sharpen skills of employees thereby improving their work efficiency. When the church leadership offer their employees study leave and support them in their endeavors, this will motivate them and increase their work morale.

\section{References}

Allen, P. (2015). Authentic Spiritual Leadership: The Mega Church Corporate Model of the New Millennium. Palis: Author House.

Anagnou, E., Fragoulis, I. (2014). The contribution of mentoring and action research to teachers' professional development in the context of informal learning. Review of European Studies, 6:133-142.

Asfaw, A. M., Argaw, M. D., \& Bayissa, L. (2015). The impact of training and development on employee performance and effectiveness: A case study of District Five Administration Office, Bole Sub-City, Addis Ababa, Ethiopia. Journal of Human Resource and Sustainability Studies, 3(04), 188.

Asim, M. (2013). Impact of Motivation on Employee Performance with effect of training: Specific to Education Sector of Pakistan. International Journal of Scientific and Research Publications, 3(9), 1-9. 
Burnes, B., \& Jackson, P. (2011). Success and Failure in Organizational Change: An Exploration of the Role of Values. Journal of Change Management, 11(2), 133-162.

Dobos, A. (2014). Experiential learning for professional development in the civil service. Procedia - Social and Behavioral Sciences, 116:5085-5090.

Fraenkel, J. R. \& Warren, N. E. (2009). How to Design and Evaluate Research in Education (4 ${ }^{\text {th }}$ ed.). New York: McGraw-Hill Publishing Company.

Hill, H. C., Beisiegel, M., \& Jacob, R. (2013). Professional development research: Consensus, crossroads, and challenges. Educational Researcher, 42:476-487.

Kariuki, J. W. (2019). An assessment of Psychosocial Anxiety Encountered by PCEA Clergy Transiting to Retirement in Kiambu County-Kenya (Doctoral dissertation, St Paul's University).

Kock, H., Ellström, P. E. (2011). Formal and integrated strategies for competence development in SMEs. Journal of European Industrial Training, 35:71-88.

Korthagen, F. (2017). Inconvenient truths about teacher learning: Towards professional development. Teachers and Teaching, 23:387-405.

Lauber, T. B., Taylor, E. J., Decker, D. J., \& Knuth, B. A. (2010). Challenges of professional development: Balancing the demands of employers and professions in federal natural resource agencies. Organization Environment, 23:446-464.

Li, K. S., Tong, C., \& Wong, A. (2014). The impact of career development on employee commitment of part-time faculty (PTF) in Hong Kong's continuing professional development (CPD) sector. Journal of Education, Society and Behavioural Science, 52-73.

Mathenge, P. M. (2015). Human Resource Management Practices of the Presbyterian Church of East Africa and Organization's Performance (The Case of PCEA St. Andrews, Nairobi Kenya).

Momanyi, N. B., \& Kaimenyi, C. K. (2015). An investigation into factors causing high nurse turnover in mission hospitals in Kenya: A case for PCEA Chogoria Hospital. International Journal of Academic Research in Business and Social Sciences, 5(3), 55.

Momanyi, N. B., \& Kaimenyi, C. K. (2015). An investigation into factors causing high nurse turnover in mission hospitals in Kenya: A case for PCEA Chogoria Hospital. International Journal of Academic Research in Business and Social Sciences, 5(3), 55.

Nardi, P. M. (2015). Doing Survey Research. London: Routledge.

Ngere, N. (2012). Reflection on retirement and related factors: The pentagon of Retirement (5R). Nairobi: Print Max.

Nkonge K. (2014). The Role of African Traditional Religion in the Formulation of Policies in Civil and Political Leadership in Africa. Research on Humanities and Social Sciences, 4(8): 30-36.

Rothwell, W. J., Hohne, C. K., \& King, S. B. (2012). Human Performance Improvement. New York: Apprentince.

Rukenya, L. N. (2019). Emotional Challenges Experienced by Spouses of Pastors in PCEA Nairobi Region, Kenya: Causes and Impact (Doctoral dissertation).

Rukenya, L. N. (2019). Emotional Challenges Experienced By Spouses of Pastors in PCEA Nairobi Region, Kenya: Causes and Impact (Doctoral Dissertation).

Shah, S. M., Sultana, N., Hassain, K. S., \& Ali, I. (2011). Impact of professional development on the performance of secondary school principals: A managerial perspective. International Journal of Management, 28:92105.

Stewart, C. (2014). Transforming professional development to professional learning. Journal of Adult Education, 43:28-33 